\title{
Indigenous and Medicinal Uses of Plants in Nech Sar National Park, Ethiopia
}

\author{
Molla Mekonnen Alemu, Subhes Bhattacharyya, Andrew Reeves, Mark Lemon \\ De Montfort University, Leicester, UK \\ Email: mollamekonnen@gmail.com
}

How to cite this paper: Alemu, M.M. Bhattacharyya, S., Reeves, A. and Lemon, M. (2017) Indigenous and Medicinal Uses of Plants in Nech Sar National Park, Ethiopia. Open Access Library Journal, 4: e3428.

https://doi.org/10.4236/oalib.1103428

Received: March 4, 2017

Accepted: March 6, 2017

Published: March 9, 2017

Copyright $\odot 2017$ by authors and Open Access Library Inc.

This work is licensed under the Creative Commons Attribution International License (CC BY 4.0).

http://creativecommons.org/licenses/by/4.0/

\begin{abstract}
For many years humans have used different parts of plants for medicinal purposes, as source of food and feed. Hence the benefits of indigenous knowledge for the development of present day sophisticated medicinal inventions cannot be overlooked. Indigenous people living in and around protected areas are still making use of plants to cure human and animal related diseases. Guji, Kore and Gamo people of Nech Sar National Park are not indifferent to this fact. Primary data were collected from these indigenous communities of the area and concerned government officers by making use of interview questions and observation. In addition to this, information was also gathered from the operational and management staff of Nech Sar National Park through semistructured questionnaire. Then data were transcribed and analyzed by making use of descriptive statistics and content analysis. The findings of the study showed, from the vegetation of Nech Sar National Park, a total of 12 plants are being used as a medicinal remedy for humans and livestock health related problems. Croton macrostachys (for skin infection), Balanites aegyptiaca (constipation and other intestinal problems), Aleo vera (joint pains and as a deworming), Acacia mellifera (treating ringworm) and Solanum incanum (treat livestock infected with water born parasites) are among the major plants which are being used as a local remedy to treat health complications by the indigenous community. Apart from this, the different parts of these plants are also used for processing food items in the household. The research found out that the local communities have strong faith on these plants as they have been used across generations so as to combat various diseases in an indigenous way. Therefore, policy and strategic actions should consider the preservation of indigenous knowledge along with biodiversity resources as indigenous technical knowledge will continue to shape up the development efforts of the present generation.
\end{abstract}

\section{Subject Areas}

Biodiversity 


\section{Keywords}

Indigenous Knowledge, Medicinal Plants, Nech Sar, Park

\section{Introduction}

Humans are highly dependent on natural resources for their very survival. Along with the evolving ecological modifications, across years, different plants have been used to treat illnesses, served as source of food and shelter too.

History tells us that, the indigenous medicinal knowledge of different plants was only given to traditional faith healers. However, for the last three decades, there has been a great shift on exploring the knowledge to harness scientific knowledge with the years old indigenous uses of plants. Many countries are also making the best out of this by creating income generation opportunities, role in public health and local economic development efforts. India, for instance, "is the second only to China with exports of 32,600 tons of medicinal raw materials worth US\$46 million annually" [1].

Indigenous technical knowledge is old as the existence of human beings on earth and it is believed that the term indigenous knowledge was first coined by an American botanist in order to study plants used by the ancient people. Since then it has been defined as "the traditional knowledge of indigenous communities, about surrounding plant diversity and as the study of how the people of a particular culture and region make use of indigenous plants" [2].

The traditional benefits of plants for treating illnesses are widely practiced in many parts of the world. For instance, in countries like Nigeria the different parts of plants are being used for physical as well as spiritual healings from generation to generation. In Nigeria, extracts of Azadirachta indica are widely used to treat malaria and it is also beneficial to treat hepatitis and intestinal disorders when the extracts are mixed with the bark and leaves of Mangifera indica. Cowley [3] also mentioned that, quinine (a cure for malaria) is also obtained from the barks of the genus Cinchona. The traditional medicinal values and benefits of plants will continue to be used by people who do not have the potential and access to modern health facilities [4].

The thousands years old medicinal system of Viet Nam on the other hand is backed by a government policy. This has helped many Vietnamese to generate income from the internal trades as well as health amenities benefits locally. With this regard, it is reported as there are 48 hospitals and institutes, more than 240 traditional medicine departments at central and provincial hospitals, and over 9000 health centres which practice traditional medicine under a government license. Reports have also showed that about 3900 plant species and 400 animal species have been used in the traditional medicine sector. However, threatened and endangered animal species such as Tigers, Rhinoceros and Bear are still being used for healing practices [5]. 
In the case of Ethiopia, it is estimated that about $80 \%$ of the population are practicing indigenous knowledge based traditional medications which are mainly extracted from plants [6] [7] [8].

Ethiopia is endowed with a floral diversity which contains about $6500-7000$ higher plant species of which $12 \%$ are estimated to be endemic. From the higher plant species, 800 - 1000 are being used in the traditional medicinal system so as to treat about 300 physical as well as mental complications. In Ethiopia, evidences show as the deep indigenous knowledge of traditional medication is not well documented and hence, there is a probability of losing that wealth of knowledge in the generations to come [9] [10] [11].

\section{Objective}

The major objective of the research is to document the vanishing indigenous knowledge on traditional uses of plants by the local communities and inform decision makers for the conservation of heritages along with biodiversity resources of Nech Sar National Park.

\section{Methodology}

\subsection{Description of the Study Area}

Nech Sar National Park (NSNP) is located in the mid of the great Rift Valley region of Ethiopia. The Park is located in two bordering Regional States, namely Southern Nations and Nationalities People's Regional State and Oromiya (Figure 1). NSNP was in established in 1974 and situated $507 \mathrm{~km}$ south of the capital, Addis Ababa. The Park covers an area of $514 \mathrm{~km}^{2}$ of which $78 \%$ is terrestrial, $15 \%$ is water and the rest marshy areas and other. The Park's location extends $5^{\circ} 51^{\prime} \mathrm{N}$ to $6^{\circ} 50^{\prime} \mathrm{N}$ and from $37^{\circ} 32^{\prime} \mathrm{E}$ to $37^{\circ} 48^{\prime} \mathrm{E}$ with an elevation range of 1108 - 1650 masl [12].

The area receives a rainfall amount of $800 \mathrm{~mm}-1200 \mathrm{~mm}$ per annum. The temperature also ranges from $16^{\circ} \mathrm{C}-37^{\circ} \mathrm{C}$. There are two cropping seasons, namely, Belg (short rainy season), Meher (main rainy season). The short rainy season starts from March to May while the main rainy season is from Jun to September [13]. To the East, the park is surrounded by the spectacular Amaro Mountains, to the west by the town of Arbaminch and to the north and south by the Great Rift Valley Lakes of Abaya and Chamo respectively [14].

The Park harbors a variety of wildlife and habitats for plain Zebra, Greater Kudu, Lesser Kudu, Water Buck, Crocodiles, Hippopotamus, etc. and a variety of terrestrial and water birds. The vegetation of the Park is composed of grassland with some bushy areas, mixed wooded land, riverine forest and underground canopy water forests.

The name Nech Sar is derived from two Amharic words "Nech" meaning "White" and "Sar" meaning "Grass" as the color of the grass which covers the undulating Nech Sar plain during the dry season becomes dry and the landscape will have a yellow-white color [15]. 

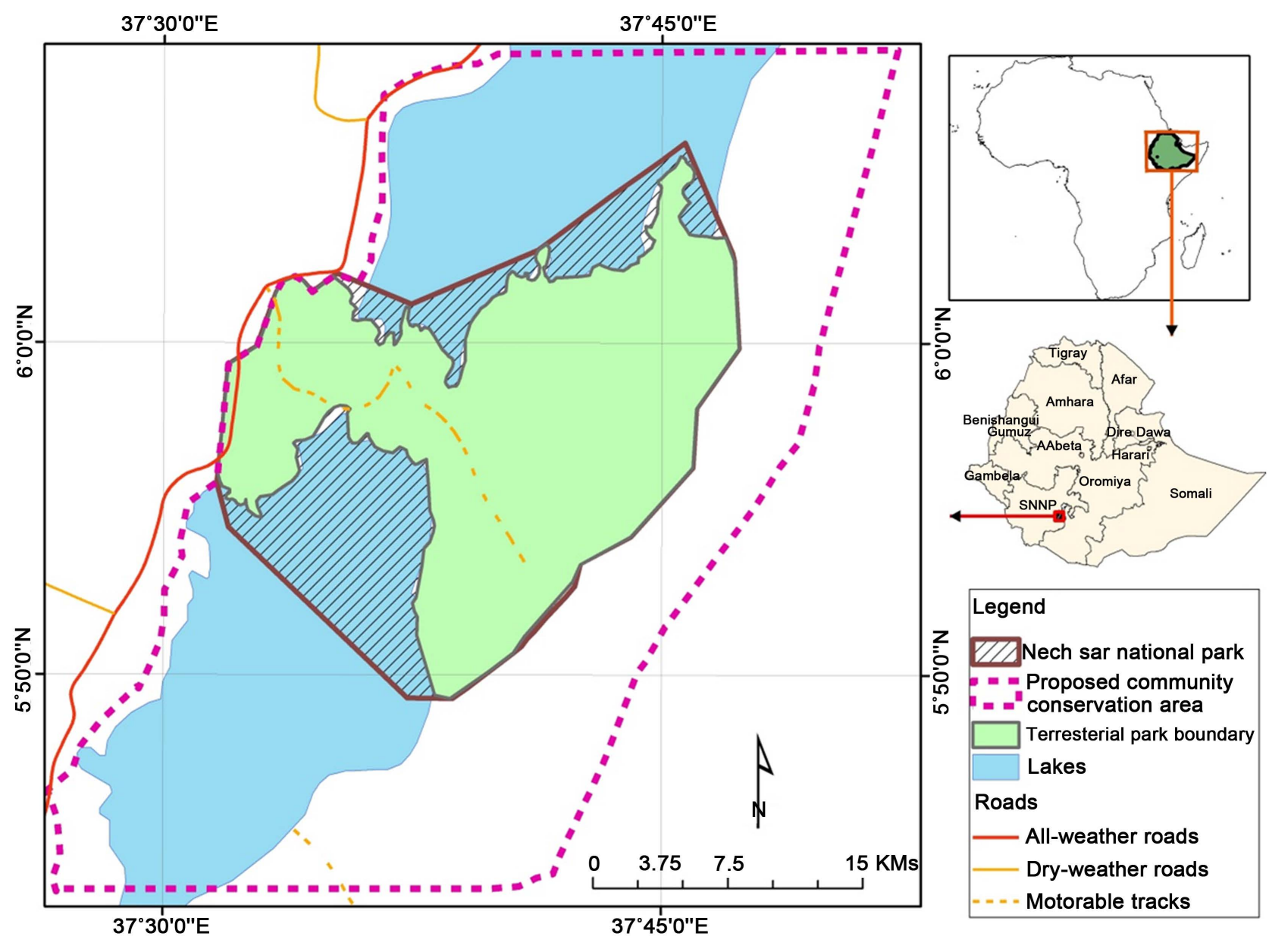

Figure 1. Location of the study area, Nech Sar National Park [16].

\subsection{Data Collection and Analysis}

Information on the indigenous benefits of the Nech Sar National Park plants was collected by making use of focus group discussions, interviews and questionnaire during June-September, 2016. The focus group discussions were held with 77 (22 female) indigenous community members of Guji, Kore and Gamo whereas interviews and questionnaires were used to gather information from 28 (4 female) management and operational staff of Nech Sar National Park. The participants for the focus group discussions were selected randomly from the three indigenous communities which are residing inside and in the nearby territories of the Park while the questionnaire was attended by the operational and management staff of the Nech Sar national Park. Discussions were mainly focused on exploring the indigenous benefits of plants. Data was then analyzed by using content analysis and descriptive statistics.

\section{Results and Discussion}

Zuberi [17] said that "the use of medicinal plants was as old as human society, in the written record, the study of herbs dates back over 5000 years to the Sumerians, who created clay tablets with lists of hundreds of medicinal plants. In 1500 
B.C., the Ancient Egyptians wrote the Ebers Papyrus, which contains information on over 850 plant medicines. In India, Ayurveda medicine has used many plants possibly as early as $1900 \mathrm{BC}$ as the earliest Sanskrit writings such as the Rig Veda, and Atharva Veda are some of the earliest available documents detailing the medical knowledge that formed the basis of the Ayurveda system later described by ancient Indian herbalists such as Charaka and Sushruta during the 1st millennium BC. The Sushruta Samhita attributed to Sushruta in the 6th century BC describes 700 medicinal plants. Also noted that the first Chinese pharmacopoeia, the Shennong Ben Cao Jing lists 365 medicinal plants and their uses, while the succeeding generations augmented on the Shennong Bencao Jing, as in the Yaoxing Lun (Treatise on the Nature of Medicinal Herbs), a 7th-century Tang Dynasty treatise on herbal medicine".

As time goes on, as a result of technological advances and economic developments in many parts of the world, the traditional way of getting medicines paved the way for the development of the modern healthcare systems. In many parts of the world considerable human developments have been observed in the $21^{\text {st }}$ century. However, extreme deprivation is also immense in different parts of the world. Access to healthcare services is challenging the poor as a result of its economic potentials. On the other hand, access to basic health care services is increasingly getting the attention of global organizations and being considered as a human rights issue by the Human Rights Commission of the United Nations, Millennium Development Goals, Sustainable Development Goals, and the World Health Organization of the United Nations and other humanitarian and development organizations [18].

According to the official statistics of the World Health Organization, 65-80\% of the developing world's population is highly dependent on plants as a remedial of health complications. This is attributed as a result of the low economic power of the poor to access modern health facilities [19].

About $80 \%$ of Ethiopia's population is believed to practice traditional medication, which is based on indigenous technical knowledge that has evolved from generation to generation [6] [7] [8].

Based on the findings of this research, the indigenous uses of the Nech Sar National Park plants is summarized in Table 1.

In the present situation, Nech Sar National Park is going through an immense human interference which is negatively affecting the biodiversity resource potential of the park (Figure 2). About $98 \%$ of the city of Arba Minch inhabitants are making use of fuel wood and charcoal as their major source of their household energy consumption [15], and that mainly comes from the vegetation of the park in an illegal way. Statistical evidence also shows that, the density and diversity of the woody vegetation is being affected by the ever increasing demand for energy and livestock pressure [20].

As a result of the manifold forms of human interference, the density and diversity of the vegetation in the park is diminishing from time to time [20]. Majority of the respondents agreed as the availability of these medicinal plants is in a decreasing pattern (Figure 3 ). 
Table 1. List of Nech Sar national park plants serving as medicinal and other benefits.

\begin{tabular}{|c|c|c|c|}
\hline S.N & $\begin{array}{l}\text { Scientific/English } \\
\text { Name of the Plant }\end{array}$ & Amharic Name & $\begin{array}{c}\text { Methods of Utilization } \\
\text { List of Nech Sar National Park } \\
\text { Medicinal Plants and Utilization Methods }\end{array}$ \\
\hline 1 & Croton macrostachyus & Bisana & $\begin{array}{l}\text { The youngest leaves of the plant will be squeezed and the extracts will be mixed } \\
\text { with water and Fenugreek ( Trigonellum foenum-graecum) for drinking by } \\
\text { humans. The extracts from the youngest leaves can also be applied } \\
\text { directly to the skin so as to cure wound and other skin infections. }\end{array}$ \\
\hline 2 & Balanites aegyptiaca & Bedeno & $\begin{array}{l}\text { The fruits of the plant are edible by humans and animals and it helps to treat } \\
\text { intestinal problems. The inner part of the bark will also be boiled with water } \\
\text { and be taken as a drink so as to treat constipation and other intestinal sicknesses. }\end{array}$ \\
\hline 3 & Aloe vera & Eret & $\begin{array}{l}\text { The leaves of the plant will be heated by the flame of a fire and will be left for } \\
\text { a while to cool it down; then the leaves will be squeezed to extract juice from } \\
\text { them. The extract will be mixed with Fenugreek and drinking water. It is well } \\
\text { known to deworm Ascaris, tapeworm, etc. It is also used to treat joint pains. }\end{array}$ \\
\hline 4 & Acacia mellifera & Tikur kontir & $\begin{array}{l}\text { Younger stem will be put on fire only on one side of the stem and the watery } \\
\text { extract will be collected from the other side of the stem and will help to treat } \\
\text { "Chirt" (Ringworm), "Quaqucha" (Tinea versicolor) and other skin infections. } \\
\text { Some also rub and dress the infected skin with Latex from leaves. }\end{array}$ \\
\hline 5 & Cordia myxa & Wanza & $\begin{array}{l}\text { The leaves of Cordia have a coarse surface and when } \\
\text { rubbed on infected skin along with its extracts it will help to } \\
\text { treat skin infections like Ringworm and Tinea versicolor. }\end{array}$ \\
\hline 6 & Solanum incanum & Embuay & $\begin{array}{l}\text { The roots of the plant are useful to treat human intestinal problems. } \\
\text { The bark of the root will be removed and the solid part of the root will be } \\
\text { soaked with salty water and then chewed just to swallow the extracts from } \\
\text { the solid root so as to relieve from intestinal problems. In addition to this, } \\
\text { Solanum also helps to treat cattle affected by water born worms as they } \\
\text { usually go to streams and rivers to drink water. Thus, boiling the } \\
\text { matured fruits until the color is changed to brown, then letting it to cool } \\
\text { for a while and then cover the fruit with clean piece of cloth and squeeze it } \\
\text { so as to take out the juice. The extracts will be sprayed in to the nostrils } \\
\text { of the affected animal forcing it to have a deep sneeze which will let the } \\
\text { water born worm to come out of the throat. }\end{array}$ \\
\hline 7 & Tamarindus indica & Korie & $\begin{array}{l}\text { The roots of the plant are well known to help the preparation of } \\
\text { local drinks like "Tela" and "Tej". Along with the main ingredients of these } \\
\text { drinks adding a piece from the roots of the plant will help to fast track the } \\
\text { fermentation process and make the drinks ready in a short period of time. }\end{array}$ \\
\hline 8 & Cissus quadrangularis & Bale arat maezen hareg & $\begin{array}{l}\text { When water is added on the roots of the plant there will be a thick mucus } \\
\text { secretion from it. This extract from the roots of the plant are mainly used to } \\
\text { treat livestock from coughing and relieve them from lung related infections. }\end{array}$ \\
\hline 9 & Salvadora persica & Yeharer Mefakiya & $\begin{array}{l}\text { The roots of the plant can be used as a tooth brush and the extracts } \\
\text { can help fight bad breath as well as bleeding of the gum. } \\
\text { It is also known to fight weak sexual performances. }\end{array}$ \\
\hline 10 & Grewia villosa & Tey & $\begin{array}{l}\text { The inner part of the bark can be used as soap } \\
\text { and it also helps to make skin and hair smooth. }\end{array}$ \\
\hline 11 & Carissa edulis & Agam & $\begin{array}{l}\text { The extract will be prepared by boiling the fruits with water until the inner } \\
\text { seeds are separated from the flesh. Once the seeds are separated from the flesh, } \\
\text { the seeds will be removed and the remaining part will be mixed thoroughly } \\
\text { with "Kocho" (false banana) and milk and get boiled altogether and taken } \\
\text { as a drink to treat women's breast pain as well as to relieve from joint pains. }\end{array}$ \\
\hline 12 & Vernonia amygdalina & Girawa & $\begin{array}{l}\text { The younger leaves will be crushed and mixed with a glass of for drinking. } \\
\text { It is highly remedial for deworming as well as intestinal complications. }\end{array}$ \\
\hline
\end{tabular}




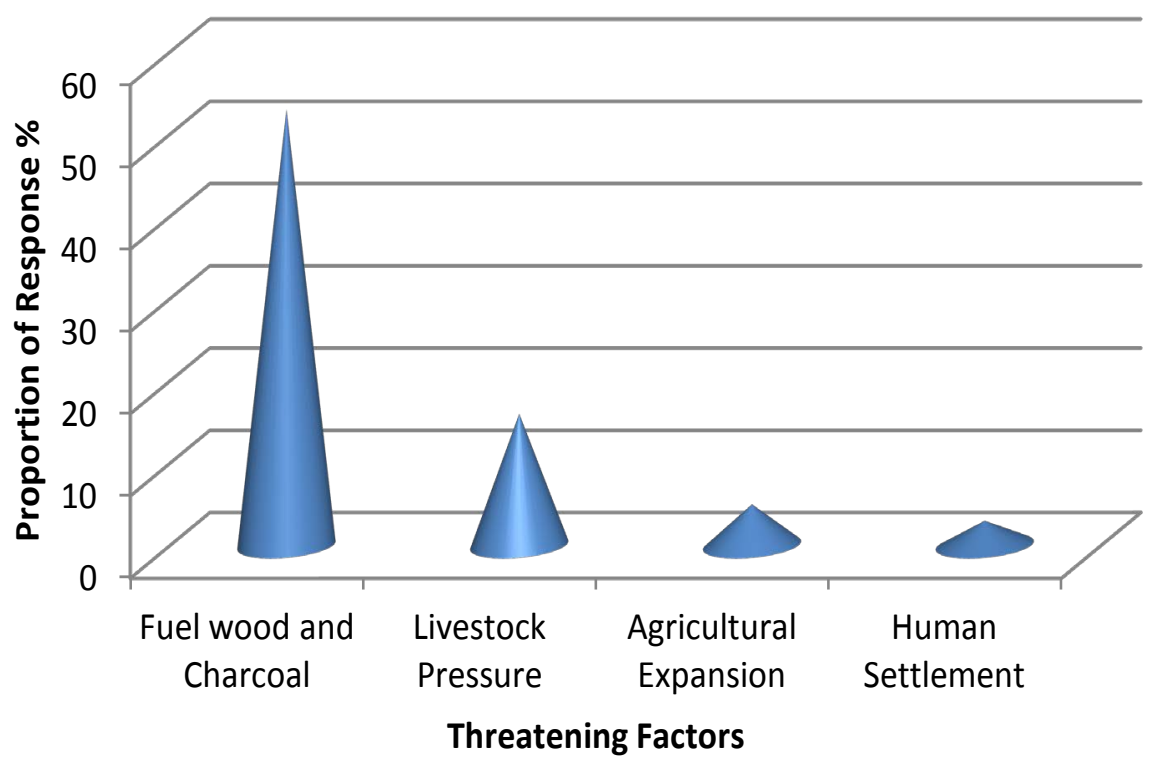

Figure 2. Threatening factors for the availability of medicinal plants.

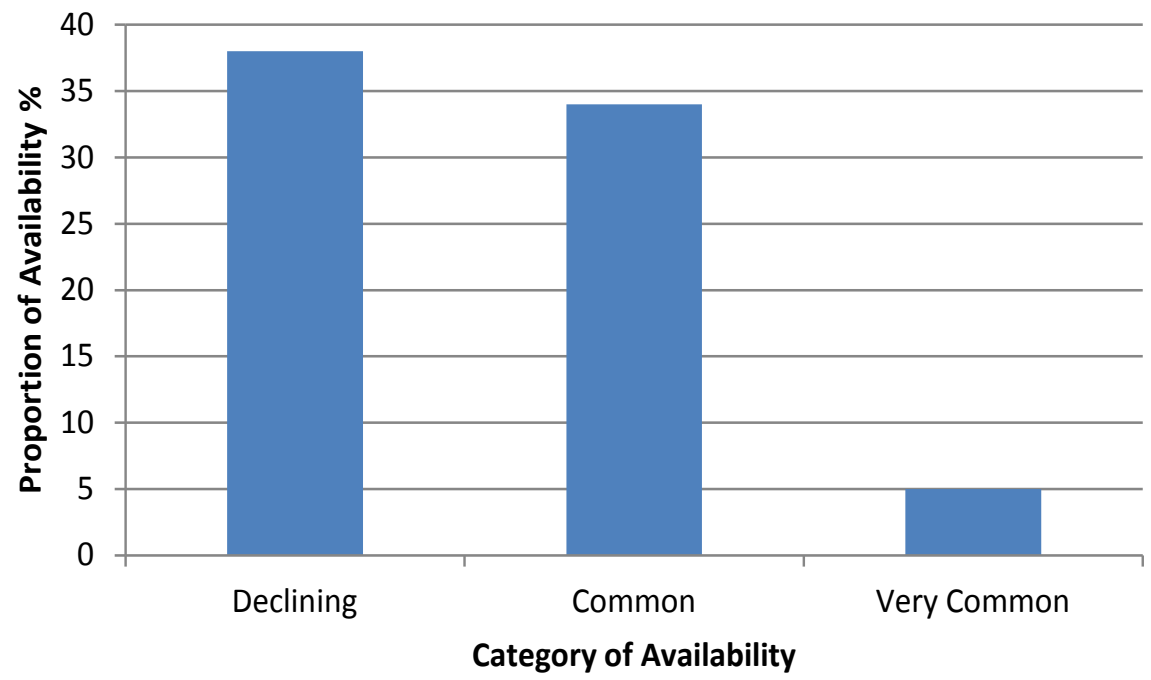

Figure 3. Analysis of response on availability of medicinal plants.

This decline would also affect the transfer of indigenous knowledge to the present generation and the economic capabilities of the local communities will also be affected since many of the indigenous people are attached to the native plant species to treat human and livestock related health problems as their primary health management system due to their standard of living (Figure 4).

In terms of preference, the lion's portion of the respondents said as the choice of the indigenous communities is inclined to the use of medicinal plants as a prime way of addressing human and livestock health problems. This is mainly because of the spiritual and indigenous attachment with the system which has crossed over generations. Apart from this, the economic implication of the modern medication system is also mentioned as another factor for the tendency to use more of the medicinal plants than the modern medications. 


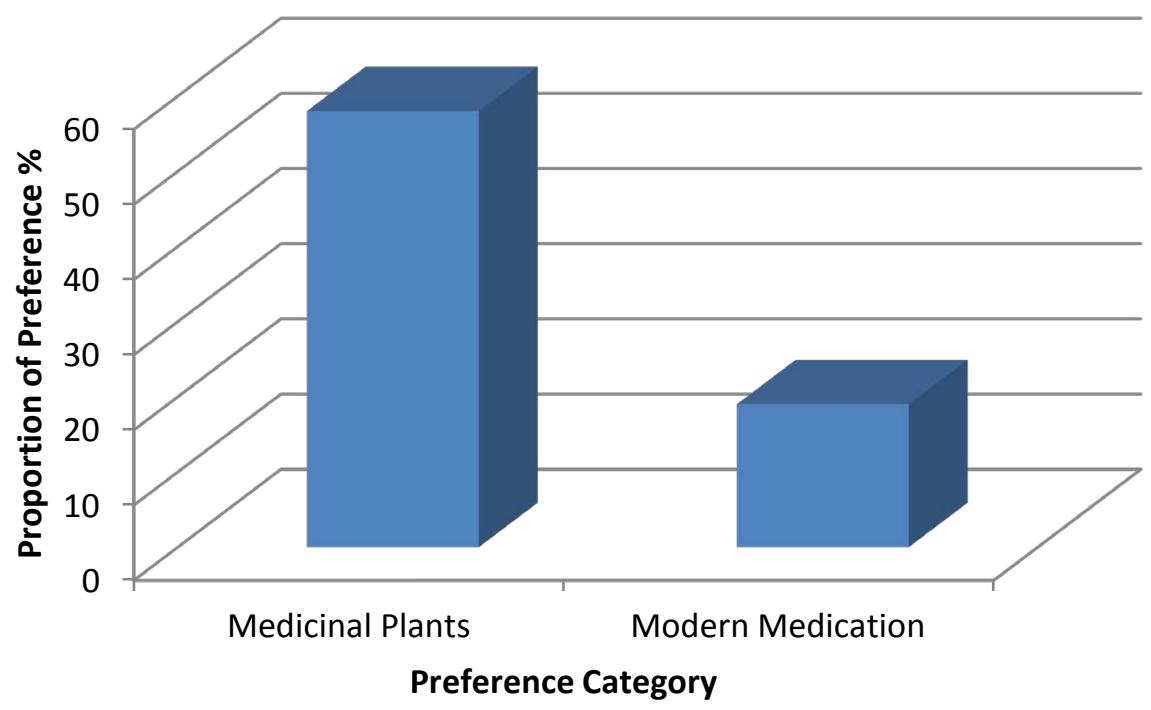

Figure 4. Respondents' preference on medicinal plants and modern medication.

\section{Conclusion}

Nech Sar National Park, a jewel in the Rift Valley region of Ethiopia, is the home of immense plant and animal biodiversity resources. The recognition and preservation of indigenous heritages and traditional knowledge on the use of plant resources are vital tools for the development of improved knowledge on innovating local based health care systems and local economic development. It is, however, a sad fact that many of the plant resources of Ethiopia are being wiped out as a result of the ever increasing needs of the fast growing population. The development and dissemination of improved energy sources coupled with other public awareness development programmes and policy and strategy enforcement are vital actions which have to be taken by policy and decision makers if the remaining plant and animal biodiversity resources of the land have to be conserved for the best uses of the present generation without compromising the benefits of generations to come.

\section{References}

[1] Kala, C.P. (2005) Indigenous Uses, Population Density, and Conservation of Threatened Medicinal Plants in Protected Areas of the Indian Himalayas. Conservation Biology, 19, 368-378. https://doi.org/10.1111/j.1523-1739.2005.00602.x

[2] Qureshi, R.A., Ghufran, M.A., Gilani, S.A., Yousaf, Z., Abbas, G. and Batool, A. (2009) Indigenous Medicinal Plants Used by Local Women in Southern Himalayan Regions of Pakistan. Pakistan Journal of Botany, 41, 19-25.

[3] Cowley, A. (2002) Alternative Medicine, New Integrative Care, News Week.

[4] Nwachukwu, C.U., Umeh, C.N., Kalu, I.G., Okere, S. and Nwoko, M.C. (2010) Identification and Traditional Uses of Some Common Medicinal Plants in Ezinihitte Mbaise L.G.A., of Imo State, Nigeria. Report and Opinion, 2, 62-66.

[5] Nguyen, D.N.V. and Nguyen, T. (2008) An Overview of the Use of Plants and Animals in Traditional Medicine Systems in Viet Nam. Traffic Southeast Asia, Greater Mekong Programme, Ha Noi. 
[6] Dawit, A. (2001) Plants as Primary Source of Drugs in the Traditional Health Care Practices of Ethiopia. Plant Genetic Resource of Ethiopia, 6, 101-113.

[7] Bekele, E. (2007) Study on Actual Situation of Medicinal Plants in Ethiopia. Japan Association for International Collaboration of Agriculture and Forestry, Addis Ababa.

[8] Mesfin, K., Tekle, G. and Tesfay, T. (2013) Ethnobotanical Study of Traditional Medicinal Plants Used by Indigenous People of Gemad District, Northern Ethiopia. Journal of Medicinal Plants Studies, 1, 32-37.

[9] Abera, B. (2014) Medicinal Plants Used in Traditional Medicine by Oromo People, Ghimbi District, Southwest Ethiopia. Journal of Ethnobiology and Ethnomedicine, 10, 40. https://doi.org/10.1186/1746-4269-10-40

[10] Kelbessa, E., Demissew, S., Woldu, Z. and Edwards, S. (2000) Some Threatened Endemic Plants of Ethiopia. In: Edwards, S. and Asfaw, Z., Eds., The Status of Some Plants in Parts of Tropical Africa, Botany 2000: NAPREC, Monograph Series No. 2, Addis Ababa University, Addis Ababa, 35-55.

[11] Birhanu, Z. (2011) Ethno-Botanical Survey on Medicinal Plants Used by Ethnic Groups of Denbia District, North-Western Ethiopia. Journal of Natural Remedies, 11, 119-123.

[12] Embassy of the Federal Democratic Republic of Ethiopia (2015) Tourism, National Parks. http://www.Ethiopia-emb.or.jp/tourism_e/park/index.html\#04

[13] Federal Democratic Republic of Ethiopia, Population Census Commission (2008) Summary and Statistical Report of the 2007 Population and Housing Census. Addis Ababa.

[14] Zafu, B. (2015) Assessment of Factors Affecting Tourist Satisfaction in Arba Minch Town. A Case Study of Nech Sar National Park. Arba Minch, Ethiopia.

[15] Desse, A.M. (2015) Summary of Attractions, Challenges, Research, Management and Partnership Issues on Nech Sar National Park. Arba Minch, Ethiopia.

[16] Ethiopian Wildlife Conservation Authority (2015) Location Map of Nech Sar National Park (on CD). Addis Ababa, Ethiopia.

[17] Zuberi, M.I. (2014) Role of Medicinal Plants in Healthcare in Africa and Related Issues: Special Emphasis to Ethiopia as an Example. Ph.D. Thesis, Ambo University, Ethiopia.

[18] Payyappallimana, U. (2009) Role of Traditional Medicine in Primary Health Care: An Overview of Perspectives and Challenges. Yokohama Journal of Social Sciences, $14,57-77$.

[19] Awoyemi, O.K., Ewa, E.E., Abdulkarim, I.A. and Aduloju, A.R. (2012) Ethnobotanical Assessment of Herbal Plants in Southwestern Nigeria. Academic Research International, 2, 50-57.

[20] Alemu, M.M. (2016) Household Energy Demand and Its Impact on the Ecological Capital of Nech Sar National Park, Ethiopia. Journal of Environmental Protection, 7, 1273-1282. https://doi.org/10.4236/jep.2016.710112 
Submit or recommend next manuscript to OALib Journal and we will provide best service for you:

- Publication frequency: Monthly

- 9 subject areas of science, technology and medicine

- Fair and rigorous peer-review system

- Fast publication process

- Article promotion in various social networking sites (LinkedIn, Facebook, Twitter, etc.)

- Maximum dissemination of your research work

Submit Your Paper Online: Click Here to Submit

Or Contact service@oalib.com 